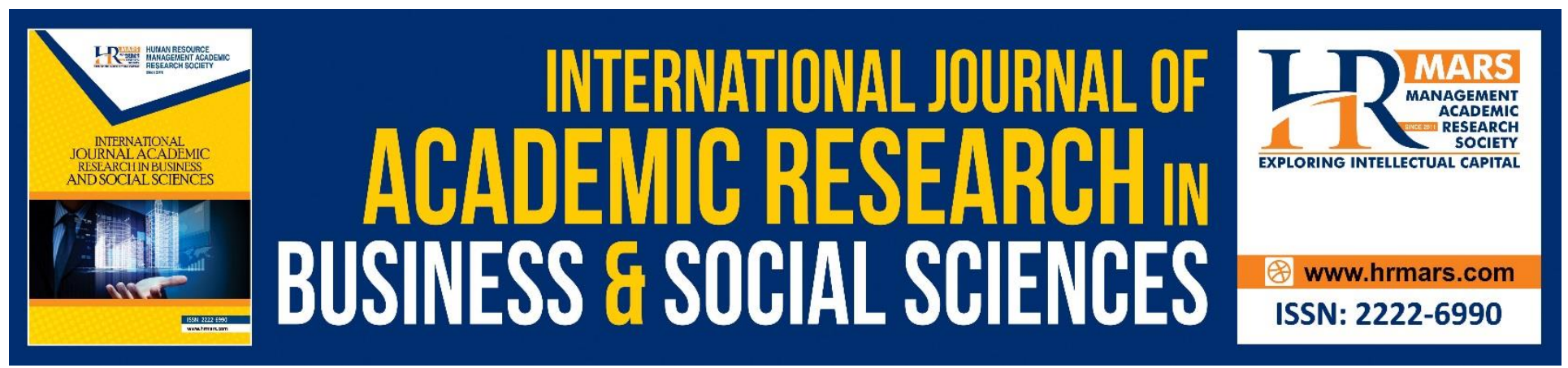

\title{
Measuring the Factors of Employees' Job Satisfaction among Lecturers in UiTM Melaka
}

Abdul Rauf Bin Ridzuan, Nor 'Aqilah binti Ahamad Baharudin, Shafinar Ismail, Ahmad Fadhly Arham, Nadia Mohd Nazri, Muhammad Fadhli Abdul Rahman

To Link this Article: http://dx.doi.org/10.6007/IJARBSS/v8-i10/4788

DOI: $10.6007 /$ IJARBSS/v8-i10/4788

Received: 17 Sept 2018, Revised: 13 Oct 2018, Accepted: 21 Oct 2018

Published Online: 04 Nov 2018

In-Text Citation: (Ridzuan et al., 2018)

To Cite this Article: Ridzuan, A. R. Bin, Baharudin, N. 'Aqilah binti A., Ismail, S., Arham, A. F., Nazri, N. M., \& Rahman, M. F. A. (2018). Measuring the Factors of Employees' Job Satisfaction among Lecturers in UiTM Melaka. International Journal of Academic Research in Business and Social Sciences, 8(10), 899-914.

\section{Copyright: (C) 2018 The Author(s)}

Published by Human Resource Management Academic Research Society (www.hrmars.com)

This article is published under the Creative Commons Attribution (CC BY 4.0) license. Anyone may reproduce, distribute, translate and create derivative works of this article (for both commercial and non-commercial purposes), subject to full attribution to the original publication and authors. The full terms of this license may be seen

at: http://creativecommons.org/licences/by/4.0/legalcode

Vol. 8, No. 10, 2018, Pg. 899 - 914

Full Terms \& Conditions of access and use can be found at http://hrmars.com/index.php/pages/detail/publication-ethics 


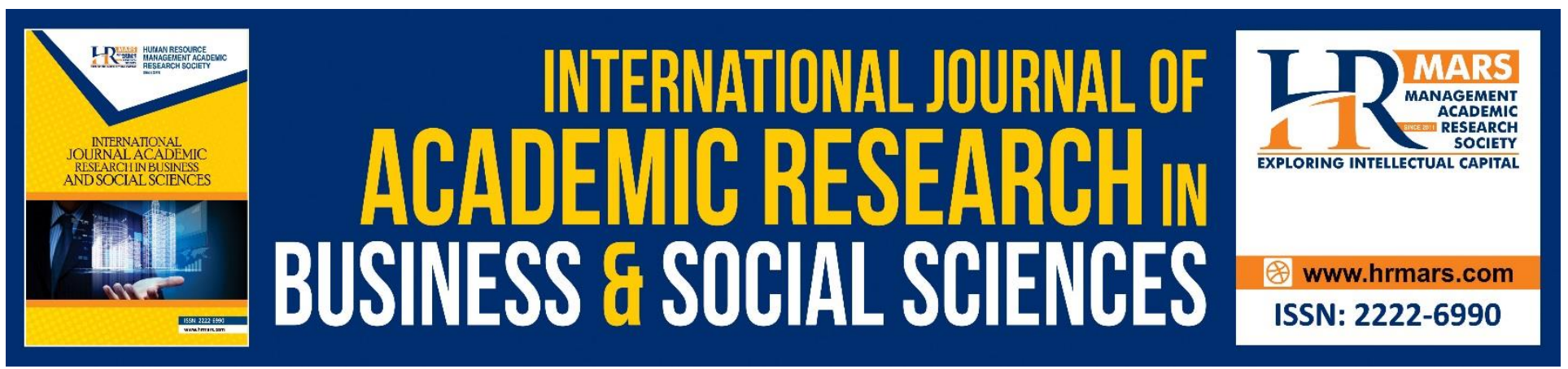

\title{
Measuring the Factors of Employees' Job Satisfaction among Lecturers in UiTM Melaka
}

\author{
Abdul Rauf Bin Ridzuan, Nor 'Aqilah binti Ahamad Baharudin, \\ Shafinar Ismail, Ahmad Fadhly Arham, Nadia Mohd Nazri, \\ Muhammad Fadhli Abdul Rahman
}

Faculty of Communication \& Media Studies, Universiti Teknologi MARA Melaka, Malaysia

\begin{abstract}
This research is basically aimed to recognize and measure the factors of employees' job satisfaction among lecturers specifically in the organization of UiTM Melaka, Campus of Alor Gajah. In the world of development, this topic is prominent in its way as every organization needs to improve their employees' satisfaction to produce a decent job (Wan Ahmad \& Abdurahman, 2015). There were many familiar present studies in this field that may be a strong stand to be referred. By using Maslow's Hierarchy of Needs Theory and Herzberg Motivator-Hygiene Theory which are related to job satisfaction field, there were four relevant factors of employees' job satisfaction; work relationships, job security, self-efficiency and payment and reward. A survey is conducted based on Krejcie and Morgan Table, $\mathrm{N}=340, \mathrm{~S}=181$. A total of 212 questionnaires were answered by the lecturers of UiTM Melaka, Campus of Alor Gajah as purposely sampling and produced the results. The findings of this research resulted Multiple Linear Regression Method that lead the positive significant on three of the factors; work relationship, self-efficiency, payment and reward while negative significant to the factor is job security. To promote the satisfaction of the staffs, the organization must consider these variables in order to gain the best brain.
\end{abstract}

Keywords: Factors, Employees' Job Satisfaction, Academic Staffs.

\section{Introduction}

Employees' job satisfaction is the most important thing seeks by every company. This is due to getting a title as a successful company, the company must have a really good job performance by the company's workers. It is not easy to have a group of the workers who can perform enough in their work. That is how the highest council of the company doing their works, they make some researches about their employees and they find out what they want to satisfy them out. In order to get catch their satisfaction is by fulfilling their wants and needs. Employees' job satisfaction is non-monetary reward where an employee went for separated from his or her direct income as an outcome of their profitable action. According to Spector (1997), satisfaction has been widely studied because of its 
INTERNATIONAL JOURNAL OF ACADEMIC RESEARCH IN BUSINESS AND SOCIAL SCIENCES

Vol. 8, No. 10, Oct. 2018, E-ISSN: 2222-6990 @ 2018 HRMARS

relevance and related to physical and mental well-being of a mankind. Job satisfaction also assumes a critical part of enhancing the financial standing of a company as well as the organization (Aronson et al., 2005).

That is how this study works as UiTM Melaka, Campus of Alor Gajah is an organization which needs to bring themselves into a successful organization. UiTM Melaka, Campus of Alor Gajah has its own staffs which divided into two; academic staffs (lecturers) and non-academic staffs (officers). This research needs the academic staffs to play their important role as it calculating their satisfaction to the organization and their works which may affect their job performance. According to a research by Mustapha (2013), universities nowadays are expected to cultivate new and latest knowledge, give the right kind of leadership and endeavor to promote uniformity and social justice. There are some main objectives in higher education which are giving the students an in-depth knowledge, analyzing the academic improvement, instructing the students, and to organize national improvement demands (Johnes and Taylor, 1990).

\section{Problem Statement}

In Malaysia, there were private and public higher education institutions that have been set up to follow up the development of the higher education. The Ministry of Higher Education has started planning huge changes in higher education by building up the Malaysian Qualification Agency and the Malaysian Qualifications Framework. The objectives and the goals have been set up especially in giving the quality of teaching, conducting research and reaching the country's standard. That is why it is significant for lecturers to be in the universities. They play the most important role especially in rising up the corporate image and producing superb graduates at the same time. They are the main reason why an organization like UiTM could stand for a long period. Since the role of academicians is exceptionally important, exertion ought to be taken in advancing loyalty among them. That is the reason job satisfaction as a stand out amongst the most imperative component in promoting loyalty of lecturers ought to be genuinely considered by all advanced education institutions. Lecturers who constantly feel unpleasant and unsatisfied with the work will influence the execution and nature of their work.

According Shafiq and Naseem (2011), messed up tasks gave by the institution may result in employees' job satisfaction in work and low inspiration. Hence, the unsatisfied environment will bring to diminished which will then disturb the performance level and the employee's confidence (Quible, 2005). In addition, the psychological factor of individuals may influence the employees' performance to finish the tasks. Subsequently, regardless of how great is the physical environment of the workstation given by an organization, the workers still cannot convey the best effort if there exists the feeling of unhappiness? This is mainly the reason for conducting the research on studying the factors of employees' job satisfaction among lecturers in UiTM Melaka, Campus of Alor Gajah. The lecturers have their rights to have a positive work environment, good payment, worth rewards, and such. Besides all of these, as an employee, they also need to produce satisfied and sincere tasks as a satisfaction to themselves as well as the company and the organization itself. In order to gain all of these things, the company especially the authority must take an initiative to provide what is needed 
INTERNATIONAL JOURNAL OF ACADEMIC RESEARCH IN BUSINESS AND SOCIAL SCIENCES

Vol. 8, No. 10, Oct. 2018, E-ISSN: 2222-6990 @ 2018 HRMARS

by their staffs. Do they need a good work relationship, high level of job security, their self-efficiency or the worth payments and the rewards?

\section{Job Satisfaction}

Job satisfaction speaks to a mix of positive and negative sentiments that employees have towards their work. It is the employees' feeling of accomplishment and how they can accomplish their work, and it is for the most part seen to be straightforwardly connected to efficiency and also to individual prosperity (Aziri, 2011). In any case, there is still no broad understanding in regards to what job satisfaction is, and in this manner, different philosopher have different understandings towards characterizing job satisfaction. As stated by Graham (1982) job satisfaction is characterized as "the estimation of one's feeling and attitudes towards one's job." For example, if the lecturers are not happy with nature of the workplace but they still know how to deal with the situation and do not let this influence them while managing the students. Job satisfaction is specifically identified with the internal sentiments of employees. Furthermore, job satisfaction is specifically related with the employees' dedication towards their organization, their work performance as well as positive vibes that motivated them to do the works perfectly.

\section{Dimensions of Employees' Job Satisfaction}

Job satisfaction is straightforwardly identified with the inward sentiments of employees. The analysed correlation demonstrates that job satisfaction and its attributions have negative and noteworthy relationship on turnover intentions. Job satisfaction and job qualities of aptitude verity, task personality and criticism diminish if the lecturers experience abnormal state turn intentions (Samad, 2006). The staffs' commitment to the company, execution and inspiration rely on job satisfaction (Noordin \& Jusoff, 2009). Advancement opportunity positively affects job satisfaction (Mustapha \& Zakaria, 2013). According to Sundar (2012), age, expertise, pay and unit are needed in bringing the level of job satisfaction. Aside the cleanliness factor, job security, employer stability, post retirement offers, recommendation system and condemnation system are the other factors that also linked to high job satisfaction.

Workers who are satisfied with their job will be more dedicated towards associations and the other way around. Dongre \& Nifadkar (2014) added that age is likewise decidedly identified with the commitment, implies that more seasoned staffs will be more dedicated to their association as contrast with youth representatives. Based on Pandey \& Khare (2012) effect of job satisfaction and the employees' commitment is compelling on employee reliability in manufacturing and service industry yet the case will be different in service industry where the employees' commitment has no effect on the staffs' loyalty however job satisfaction does.

\section{Work Relationship}

A strong workplace is portrayed by employee perceptions that co-workers are involved in their work and the managers give support and encourage workers' work endeavours (Moos, 1981). Supportive work environment are related for the most part with enhanced work-place attitudes and more productive practices (Day and Bedeian, 1991). 
Supervisor support is the degree which employees see that supervisors offer workers support, consolation and concern (Burke, Borucki and Hurley, 1992). The level of supervisor support may influence workers' performance, in any case, the impact might be intervened by role pressure. For instance, an essential way by which supervisors encourage worker execution is by giving key resources such as sufficient equipment and training (Guzzo and Gannett, 1988). Two-way communication is the most pertinent between the management and academic staff to create a conducive and friendly environment.

Various researchers opined that having friendly and supportive friends add to expanded job satisfaction (Kreitner \& Kinicki, 2001). As indicated by Madison (2000), members who needed help from kindred specialists, will probably experience the ill effects of employment disappointment. Another study found that positive relationships with kindred labourers upgrade work satisfaction (Berta, 2005).

\section{Job Security}

Job satisfaction has a clear relationship with security as the employees are much pleased with their jobs with better security. Many researchers have found that employees with permanent jobs are more pleased with their jobs as compare to the employees on contract basis. It was found to have a positive relationship with job satisfaction as indicated by various researchers (Baloch, 2009). Consequently, lecturers are allegedly satisfied when there are promotional opportunities and it was recommended by Kosteas (2009) that academic staffs are committed and persuaded when they accept or imagine that there are advancements in a brief time frame. Hence, this expanded their confidence, execution and job satisfaction, as detailed by Saba (2011) when she expressed that the respondents of her research were happy with the work itself, payment, working conditions, job security and co-workers. Nonetheless, in her study, there were a significant number of educators who were disappointed with the procedure of promotion in their job. In a research done by Nabi (2003) found that job security and career progress can be related positively to career success.

\section{Self-Efficiency}

When women and men consider about their career decisions, the probability of picking a specific career is affected by desires for success in those occupations (Betz and Hackett, 1981). Women are reported with more elevated amounts of self-efficiency for job success for professions that are female dominated while men are reported with more elevated amounts of self-efficiency for job success while considering careers that are male dominated. With the end goal for one to build up an interest or preference for a specific occupation, one must think about critical results, named outcome valence, for example, high wage. Then, see that having such an occupation will be instrumental in giving the result. For instance, turning into an engineer will bring about a high salary. While thinking about a few results and instruments, higher esteems will bring about more interest. For really settling on a word related decision, another idea of significance is hope, the subjective likelihood that a given demonstration will prompt a result. For instance, if engineer is a conceivable decision, what is the subjective likelihood that one will effectively total educational requirements (Brooks and Betz, 1990). 


\section{Payment and Reward}

According to Heathfield, S.M. (2012), salary is a settled measure of cash or remuneration paid to an employee by an employer in return for a profitable work performed. Compensation framework assumes an essential part in deciding an employee's level of job satisfaction. The developing needs of families with higher living costs force workers looking for higher salary that can ensure their future and life fulfillment. On the off chance that people trust they are not remunerated well, a condition of enthusiastic disappointment will create. This passionate error will develop and collect finished circumstances along these lines make representatives miserable and unsatisfied working for the association. Pouliakas (2010) found that there is a huge negative connection between small extra installments and the fulfillment of laborers with the real occupation itself. Money related impetuses positively affect workers' utility and execution as long as they are sufficiently extensive. As Millán et al. (2011) also revealed that having higher work salaries improve the probability of being happy with the sort of work.

\section{Research Methodology}

The explanatory research is likewise referred as an analytical study. This type of research also known to identify any of the causal links between the variables or the factors that belong to the research problem that has been stated in the research questions. This research design helps to provide the understanding of the relationship between the variables fixed in this study. For example, this design enables to fulfill the main purpose of the research which is to identify the factors of employees' job satisfaction among lecturers in UiTM Melaka, Campus of Alor Gajah. As stated by Gay and Airaasia (2003), the basic structure of a research can be seen through its research design because the research design represents the research main ideology. It is also essential due to achieve the research objectives accurately. As referred to the Krejcie \& Morgan (1970) from the table of Krejcie \& Morgan, from the population of $340(\mathrm{~N})$, the sample group is focused to $181(\mathrm{~S})$ staffs out of 340 lecturers in UiTM Campus of Alor Gajah. The 181 sample is picked randomly and generally without any bias in choosing the respondents (Abdul Rauf Ridzuan et al., 2015). The set of questionnaires that have been used as the instrument in this study consist of three sections which are Section A, Section B, and Section C. There are 44 questions altogether.

\section{Results and Discussions}

a) Profile of the lecturers of UiTM Campus of Alor Gajah

The profile of the sample is discussed in terms of nine characteristics: gender, age and education level, experience, faculty, teaching grade, industry experience and happiness. 
INTERNATIONAL JOURNAL OF ACADEMIC RESEARCH IN BUSINESS AND SOCIAL SCIENCES Vol. 8, No. 10, Oct. 2018, E-ISSN: 2222-6990 @ 2018 HRMARS

\begin{tabular}{|c|c|c|}
\hline ITEM & FREQUENCY & PERCENTAGE \% \\
\hline $\begin{array}{l}\text { GENDER } \\
\qquad \text { Male } \\
\text { - } \text { Female }\end{array}$ & $\begin{array}{c}71 \\
141\end{array}$ & $\begin{array}{l}33.5 \\
66.5\end{array}$ \\
\hline 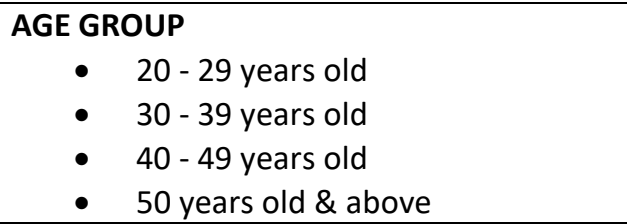 & $\begin{array}{c}19 \\
125 \\
48 \\
20\end{array}$ & $\begin{array}{c}9.0 \\
59.0 \\
22.6 \\
9.4\end{array}$ \\
\hline 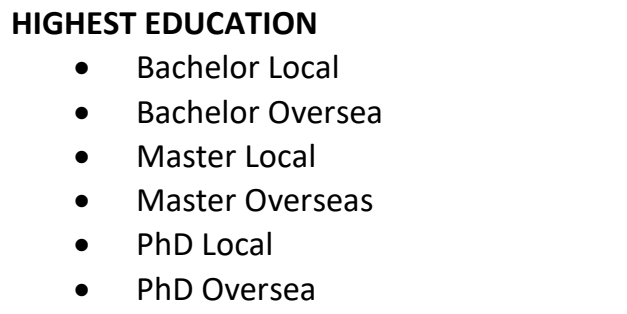 & $\begin{array}{c}5 \\
3 \\
170 \\
15 \\
16 \\
3\end{array}$ & $\begin{array}{c}2.4 \\
1.4 \\
80.2 \\
7.1 \\
7.5 \\
1.4\end{array}$ \\
\hline 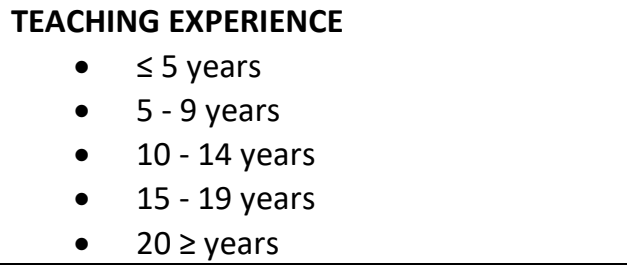 & $\begin{array}{l}34 \\
77 \\
58 \\
18 \\
25\end{array}$ & $\begin{array}{c}16.0 \\
36.3 \\
27.4 \\
8.5 \\
11.8 \\
\end{array}$ \\
\hline $\begin{array}{l}\text { FACULTY } \\
\text { - } \text { Faculty of Business and } \\
\text { - } \text { Management } \\
\text { - Faculty of Accounting } \\
\text { - } \text { Tourism } \\
\text { - Faculty of Art and Design } \\
\text { - } \text { Meculty of Communication and } \\
\text { - ACIS Studies } \\
\text { - } \text { Law } \\
\end{array}$ & $\begin{array}{c}55 \\
34 \\
11 \\
52 \\
13 \\
15 \\
26 \\
6\end{array}$ & $\begin{array}{c}25.9 \\
\\
16.0 \\
\\
5.2 \\
24.5 \\
\\
6.1 \\
7.1 \\
12.3 \\
2.8\end{array}$ \\
\hline $\begin{aligned} \text { SALARY } & \\
\text { - } & \leq \mathrm{RM} 2000 \\
\text { - } & \mathrm{RM} 2001-\mathrm{RM} 3000 \\
\text { - } & \mathrm{RM} 3001 \text { - RM4000 } \\
\text { - } & \mathrm{RM} 4001 \text { - RM5000 } \\
\text { - } & \mathrm{RM} 5001 \geq\end{aligned}$ & $\begin{array}{c}2 \\
21 \\
13 \\
36 \\
140\end{array}$ & $\begin{array}{c}0.9 \\
9.9 \\
6.1 \\
17.0 \\
66.0\end{array}$ \\
\hline
\end{tabular}


INTERNATIONAL JOURNAL OF ACADEMIC RESEARCH IN BUSINESS AND SOCIAL SCIENCES Vol. 8, No. 10, Oct. 2018, E-ISSN: 2222-6990 @ 2018 HRMARS

\begin{tabular}{|c|c|c|}
\hline $\begin{array}{cl}\text { TEACHING GRADE } \\
\text { • } & \text { PTFT } \\
\text { - } & \text { DM } 41 / 42 \\
\text { - } & \text { DM } 45 / 46 \\
\text { - } & \text { DM } 51 / 52 \\
\text { - } & \text { DM } 53 / 54\end{array}$ & $\begin{array}{l}22 \\
10 \\
71 \\
97 \\
12\end{array}$ & $\begin{array}{c}10.4 \\
4.2 \\
33.5 \\
45.8 \\
5.7\end{array}$ \\
\hline $\begin{array}{l}\text { EXPERIENCE IN INDUSTRY } \\
\text { - Yes } \\
\text { - } \quad \text { No }\end{array}$ & $\begin{array}{c}158 \\
54\end{array}$ & $\begin{array}{l}74.5 \\
25.5\end{array}$ \\
\hline $\begin{array}{l}\text { WORKING HAPPINESS } \\
\text { - Yes } \\
-\quad \text { No }\end{array}$ & $\begin{array}{c}169 \\
43\end{array}$ & $\begin{array}{l}79.7 \\
20.3\end{array}$ \\
\hline
\end{tabular}

Table 1: Frequency Analysis

The table above shows a clear summary of the research frequency analysis of the respondents. These are the respondents' background personal data which are related to the research topic and each of them would be useful information. Based on the table, the frequency of the gender distribution was preceded by female respondents which $66.5 \%$ while male respondents amount are only half of female. Next, the highest distribution for the age group is the group of 30 to 39 years old which $59 \%$ from the respondent are dominated by this group. From the frequency distribution table, the majority circle of the highest education part is the group of local Master graduates which represents $80.2 \%$ of the whole group of respondents.

The teaching experience shows moderate amount but the highest is 5 to 9 years where $36.3 \%$ of the lecturers included. In addition, another useful part of the research is the faculty where the highest value are came from Faculty Business and Management which $25.9 \%$ of lecturers are from this faculty. Next, the highest salary rate is RM5000 and above where dominated until $66.0 \%$. Then, the frequency distribution of the lecturer's teaching grade shows the highest at DM51/52 which $45.8 \%$ mostly. Most of the lecturers have their experience in industry which $74.5 \%$ of them ticked 'yes' for this item and $79.7 \%$ of the respondents are happy working in this institution (UiTM).

\section{b) Testing Relationship - Multiple Regression Analysis}

\section{Model Summary}

\begin{tabular}{|c|c|c|c|c|}
\hline Model & R & R Square & Adjusted R Square & $\begin{array}{c}\text { Std. Error of the } \\
\text { Estimate }\end{array}$ \\
\hline 1 & $.782 \mathrm{a}$ & .612 & .605 & .34787 \\
\hline
\end{tabular}

Table 2 Model Summary for Multiple Linear Regression Analysis 
INTERNATIONAL JOURNAL OF ACADEMIC RESEARCH IN BUSINESS AND SOCIAL SCIENCES

Vol. 8, No. 10, Oct. 2018, E-ISSN: 2222-6990 @ 2018 HRMARS

\section{Coefficients}

\begin{tabular}{|l|c|c|c|c|c|}
\hline \multirow{2}{*}{ Model } & \multicolumn{2}{|c|}{$\begin{array}{c}\text { Unstandardized } \\
\text { Coefficients }\end{array}$} & $\begin{array}{c}\text { Standardized } \\
\text { Coefficients }\end{array}$ & T & Sig. \\
\cline { 2 - 4 } & B & Std. Error & Beta & & \\
\hline Constant & .116 & .177 & & .655 & .513 \\
Work Relationship & .210 & .056 & .219 & 3.737 & .000 \\
Job Security & .055 & .059 & .062 & .928 & .355 \\
Self-Efficiency & .545 & .066 & .466 & 8.259 & .000 \\
Payment and & .186 & .048 & .210 & 3.858 & .000 \\
Reward & & & & \\
\hline
\end{tabular}

Table 3 Coefficient for Multiple Regression Analysis References

\section{H1: The more the work relationship the higher the level of employee self-satisfaction}

The hypothesis which refers to the work relationship indicated the second highest Beta value which is $(\beta=0.219)$ at significant level $(p=0.000)$. Thus, the null hypothesis is accepted because the significant level is $(p<0.05)$. As indicated by Friedlander and Margulies (1969), it was found that management and friendly staff relationships add to the level of job satisfaction. This proves that a good relationship in the workplace might help the employees to achieve to the level of job satisfaction.

H2: The more the job security the higher the level of employee self-satisfaction.

The hypothesis which refers to the job security indicated the lowest Beta value which is $(\beta=0.062)$ at significant level $(p=0.355)$. Thus, null hypothesis is rejected and alternate hypothesis is accepted because the significant level is $(p<0.05)$. This results opposite to a research by Robbins (2001) who advocates that working conditions will impact job satisfaction of an employee, as they care about a comfortable physical workplace. Thus this will render a more positive level of job satisfaction.

H3: The more the self-efficiency the higher the level of employee self-satisfaction.

The hypothesis which refers to the self-efficiency indicated the highest Beta value which is $(\beta=0.466)$ at the significant level $(p=0.000)$. Thus, the null hypothesis is accepted because the significant level is $(p<0.05)$. According to a research by Day (1999), there is presently a struggle for the professionalism skill, in pre-service and in-service stages which reflects the 'expanding complexities and inconsistencies of lecturers' work'.

H4: The more the payment and reward the higher the level of employee self-satisfaction.

The hypothesis which refers to the payment and reward indicated the second highest Beta value which is $(\beta=0.210)$ at significant level $(p=0.000)$. Thus, the null hypothesis is accepted because the significant level is $(p<0.05)$. It is logical to expect that activity rewards such as high pay ought to be notable to employee even during the beginning periods of a job, while the expenses related with a 
INTERNATIONAL JOURNAL OF ACADEMIC RESEARCH IN BUSINESS AND SOCIAL SCIENCES Vol. 8, No. 10, Oct. 2018, E-ISSN: 2222-6990 ㄷ 2018 HRMARS

given employment such as varieties workload, deadlines and lacking resources most likely turn out to be more detectable after some time (Rusbult and Farrell, 1983).

\begin{tabular}{|l|l|c|}
\hline \multicolumn{1}{|c|}{ HYPOTHESIS } & Sig. & ACCEPTED / REJECTED \\
\hline $\begin{array}{l}\text { H1: The more the work relationship } \\
\text { the higher the level of employee } \\
\text { self-satisfaction }\end{array}$ & .000 & HO ACCEPTED \\
\hline $\begin{array}{l}\text { H2: The more the job security the } \\
\text { higher the level of employee self- } \\
\text { satisfaction. }\end{array}$ & .355 & HO REJECTED \\
\hline $\begin{array}{l}\text { H3: The more the self-efficiency the } \\
\text { higher the level of employee self- } \\
\text { satisfaction. }\end{array}$ & .000 & HO ACCEPTED \\
\hline $\begin{array}{l}\text { H4: The more the payment and } \\
\text { reward the higher the level of } \\
\text { employee self-satisfaction. }\end{array}$ & .000 & HO ACCEPTED \\
\hline
\end{tabular}

Table 4 : Summary of Hypothesis Testing - Multiple Linear Regression Analysis

The summary of hypothesis testing based on Multiple Linear Regression analysis above shows different result as compared to the Pearson Correlation testing. To decide whether the null hypothesis ( $\mathrm{Ho}$ ) can be accepted or to accept the alternate hypothesis ( $\mathrm{Ha}$ ), it is compulsory to read the significant value in the Coefficient for Multiple Regression Analysis must be below than $(<0.05)$ at significant level of 2-tailed. Thus, the null hypothesis (Ho) that accepted are $\mathrm{H} 1(0.000), \mathrm{H} 3(0.000)$ and $\mathrm{H} 4$ (0.000). The remaining null hypothesis which is $\mathrm{H} 2$ is rejected due to significant value is more than 0.355 but accepted the alternate hypothesis ( $\mathrm{Ha})$. 
Factors of Employees' Job Satisfaction among Lecturers in

UiTM Melaka, Campus of Alor Gajah
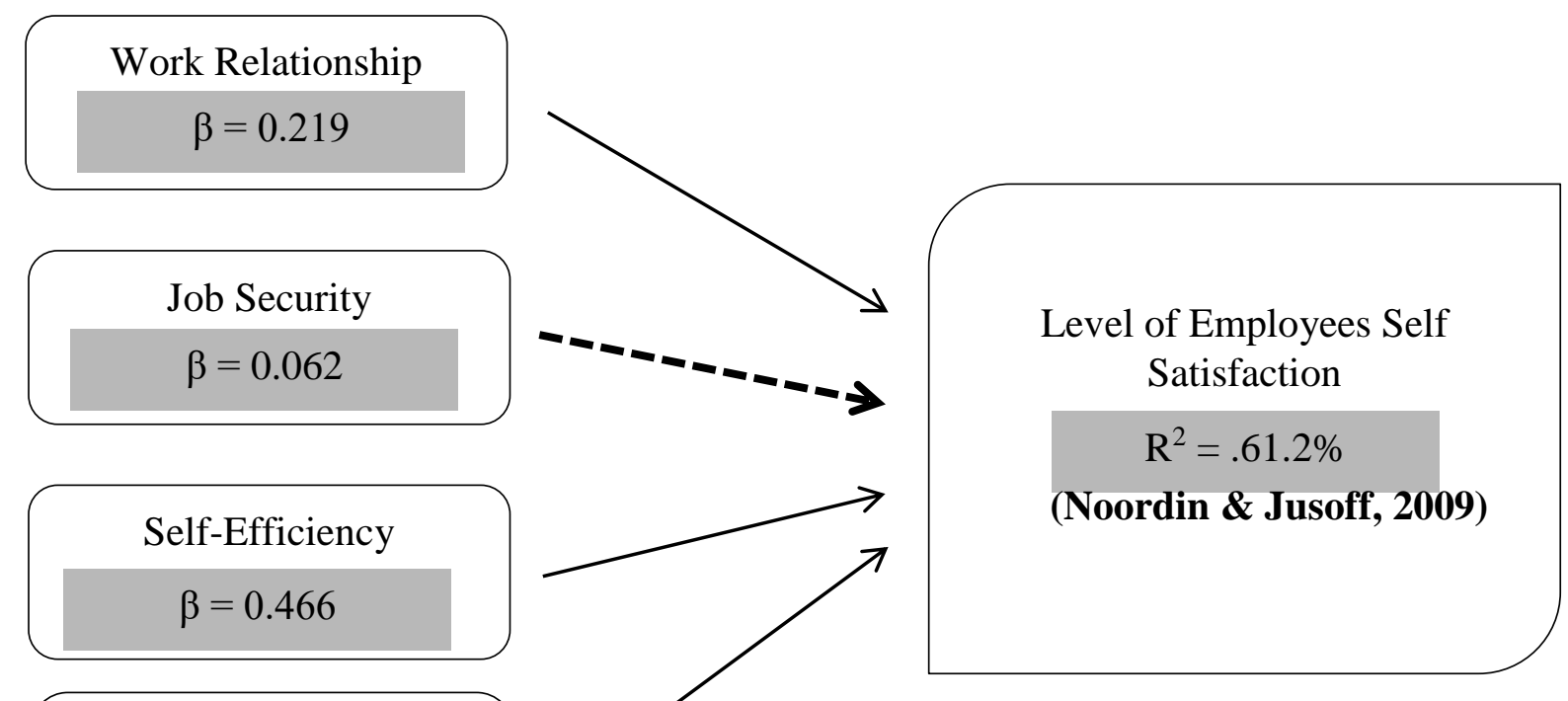

Payment and Reward

$$
\beta=0.210
$$

(Maslow, 1943)

Independent Variable

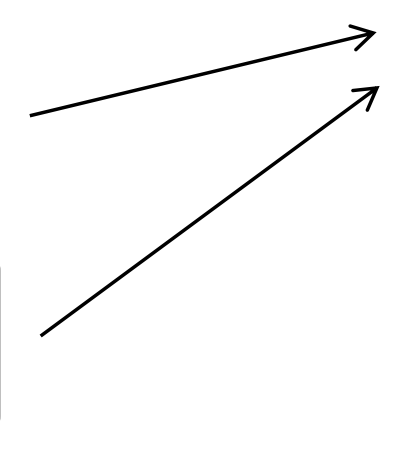

(Noordin \& Jusoff, 2009)

Dependent Variable

Figure 1 Validated Research Framework
$\longrightarrow=$ Null Hypothesis $(\mathrm{Ho})$ is accepted
$\boldsymbol{- \boldsymbol { D }} \rightarrow \mathbf{=}$ Null Hypothesis $(\mathrm{Ho})$ is rejected 
Based on the Beta $(\beta)$ value reading indicated the significant towards the interaction between the independent and dependent variable. The highest Beta $(\beta)$ value indicated the strongest significant reaction of the independent variable directly towards the dependent variable. Thus, the most significant or the strongest relations of the independent variable is the factors of work relationship $(\beta=0.640)$. Hence, $74.0 \%$ of the variance in dependent variables can be explained by independent variables (work relationship, job security, self-efficiency as well as payment and reward). To conclude, there are still another $26 \%$ is explained by other factors which are not covered in this study.

\section{Conclusion}

All in all, the figure above shows the validated research framework which is accepted and approved as all the data collected have been analyzed. Based on the table above, the factors which represent the independent variables of this research (work relationship, self-efficiency as well as payment and reward) are accepted and useful for this and the next research. Unfortunately, the factor of job security is not valid as the lecturers of UiTM Melaka, Campus of Alor Gajah did not include this factor for their self-satisfaction while working. Thus, the null hypothesis (Ho) of the work relationship, selfefficiency and payment and reward are accepted while job security null hypothesis (Ho) is rejected and alternate hypothesis $(\mathrm{Ha})$ is accepted. Overall, most of the lecturers here are very happy working at UiTM Melaka and satisfied with their organization.

\section{Acknowledgement}

Researchers would like to say thank you to Deputy Rector of Research in UiTM Cawangan Melaka, Associate Prof Dr Shafinar Ismail and Melina Mahpuz, Deputy Dean of Research and Industry Linkage from Faculty of Communication \& Media Studies, UiTM Shah Alam for their encouragement and motivation to do this research.

\section{Corresponding Author}

Abdul Rauf Ridzuan (PhD), Faculty of Communication \& Media Studies, UiTM Cawangan Melaka, Malaysia. Email: abdulrauf@melaka.uitm.edu.my

\section{References}

Achieng'Odembo, S. T. E. L. L. A. (2013). Job Satisfaction And Employee Performance Within The Telecommunication Industry in Kenya: a Case Of Airtel Kenya Limited. Doctoral Dissertation, Kenyatta University.

Mehrad, A. (2011). The impact of income on academic staff job satisfaction at public research Universities, Malaysia. Journal of Educational, Health and Community Psychology, Vol. 3(2): $23-27$.

Anitha, R. (2011) A study on job satisfaction of paper mill employees with special reference to udumalpet and palani taluk. Journal of Management and Science 12.

Aronson, K.R., Laurenceau, J.P., Sieveking, N., Bellet, W. (2005). Job satisfaction as a function of job level. Admin. Policy Mental Health. 32 (3): 285-291.

Babbie, E. (1990). Survey research methods. Belmont, CA: Wadsworth. 
INTERNATIONAL JOURNAL OF ACADEMIC RESEARCH IN BUSINESS AND SOCIAL SCIENCES Vol. 8, No. 10, Oct. 2018, E-ISSN: 2222-6990 @ 2018 HRMARS

Bandura, A. (1986). Social Foundations of Thought and Action: A social cognitive theory. Eaglewood Cliffs, NJ: Prentice-Hall.

Baloch, Q.B. (2009), "Effects of job satisfaction on employees motivation \& turn over intentions", Journal of Managerial Sciences, Vol. II No. I, pp. 1-21.

Berta, D. (2005). Put on a happy face: High morale can lift productivity. Nation's Restaurant News, 39 (20), p. 8.

Betz, N. E., \& Hackett, G. (1981). The relationship of career-related self-efficacy expectations to perceived career options in college men and women. Journal of Counselling Psychology, 28, 399-410.

Berg, P. (1999). The effects of high performance work practices on job satisfaction in the United States steel industry. Relations industrielles/Industrial relations, 54(1), 111-135.

Bowen, B. E. and R. B. Radhakrishna. (1991). Job satisfaction of Agricultural Education Faculty: a constant phenomenon. Journal of Agricultural Education, 32 (2): 16-22.

Bozeman, B. \& Gaughan, M., (2011). Job Satisfaction among University Faculty: Individual, Work, and Institutional Determinants. Journal of Higher Education, 82(2), 154-186.

Brooks, L., \& Betz, N. E. (1990). Utility of expectancy theory in predicting occupational choices in college students. Journal of Counselling Psychology, 37, 57-64.

Burns, N., \& Grove, S. K. (2009). The practice of nursing research: appraisal, synthesis, and generation of evidence. St. Louis, Mo: Saunders Elsevier.

Burke, Michael J., Chester C. Borucki and Amy E. Hurley. (1992). "Reconceptualizing Psychological Climate in a Retail Service Environment: A Multiple-Stakeholder Perspective," Journal of Applied Psychology, 77(5): 717-729.

Cameron, K. (2012). Effects of virtuous leadership of organizational performance. In S. I. Donaldson, M. Csikszentmihlyi., \& J. Nakamura (Eds.), applied positive psychology:

Improving everyday life, health, schools, work and Society (pp. 171-183). East Sussex: Routledge.

Clark, A. E. (1997). Job satisfaction and gender: why are women so happy at work? Labour Economics, 4(4), 341-372.

Cronbach, L.J. (1951). Coefficient alpha and the internal structure of tests. Psychometrika, 16(3), 297-334.

Coleman, J.C. (1976). Abnormal Psychology and Modern Life (Indian reprint), Taraporewalla, Bombay.

Creswell, J.W. (1994). Research Design: Qualitative \& Quantitative Approaches. London: SAGE Publications.

Day, C., Flores, M. A., \& Viana, I. (2007). Effects of national policies on teachers' sense of professionalism: Findings from an empirical study in Portugal and in England. European Journal of Teacher Education, 30(3), 249-265.

Day, C. (1999) Developing teachers. The challenges of lifelong learning. London, Falmer Press.

Day, David V. and Arthur G. Bedeian. (1991). "Predicting Job Performance Across Organizations:

The Interaction of Work Orientation and Psychological Climate," Journal of Management, 17(Fall): 589-600.

De Vaus, D. A. (2001). Research Design in Social Research. London: SAGE. 
INTERNATIONAL JOURNAL OF ACADEMIC RESEARCH IN BUSINESS AND SOCIAL SCIENCES

Vol. 8, No. 10, Oct. 2018, E-ISSN: 2222-6990 @ 2018 HRMARS

Dongre AP, Nifadkar RS (2014) To Study The Impact Of Job Satisfaction And Demographic Factors

On Organizational Commitment Among Girls' College, Pune, India. BORJ 3.

Dufty, N. F. (1967) Blue collar contrast. International Journal of Comparative Sociology, 8, 209-

217.

Fauziah Noordin \& Kamaruzaman Jusoff, (2009). Levels of job satisfaction amongst Malaysian academic staff. Asian Social Science, Vol. 5, No. 5: $122-128$.

Fisher, J. E., Mohanty, A., Herrington, J. D., Koven, N. S., Miller, G. A., and Heller, W. (2004).

Neuropsychological evidence for dimensional schizotypy: implications for creativity and psychopathology. J. Res. Pers. 38, 24-31.

Friedlander, F. and Margulies N. (1969) Multiple Impacts of Organization Climate and Individual Values System upon Job Satisfaction, Personnel Psychology. 22, pp. 177-183.

Graham, G.H. (1982). Understanding human relations. The individual, organisations, and management. Science Research Associates, Chicago Inc.

Guzzo, Richard A. and B.A. Gannett. (1988). "The Nature of Facilitators and Inhibitors of Effective

Task Performance." In Facilitating Work Effectiveness, edited by F.D. Schoorman and B. Schneider. Lexington, MA: Lexington Books.

Hall, B. W., Pearson, L. C., \& Carroll, D. (1992). Teachers' long-range teaching plans: A discriminant analysis. The Journal of educational research, 85(4), 221-225.

Heathfield, S.M.(2012). Salary. Retrieved on 1 September 2012 from http://human resources.about.com/od/glossarys/g/salary.htm

Hemmasi, M., L. A. Graf and J. A. Lust. (1992). Correlates of pay and benefit satisfaction: the unique case of public university faculty. Public Personnel Management, 21 (4): 429-443.

Herzberg, F. (2005). Motivation-hygiene theory. J. Miner, Organizational Behavior I: Essential Theories of Motivation and Leadership, 61-74.

Hodson, R. (1989). Gender differences in job satisfaction. The Sociological Quarterly, 30(3), 385-399.

Holmes N, Carvalho G and Powers M. (2010). Reward systems \& incentives. Human Resources

\& Labor Management, 1-8.

Ismail Hussein Amzat and Datuk Abdul Rahman Idris, (2012) "Structural equation models of

management and decision-making styles with job satisfaction of academic staff in

Malaysian research university", International Journal of Educational Management, Vol. 26 Issue: 7, pp.616-645.

Johnes, J. and Taylor, J. (1990), Performance Indicators in Higher Education: Buckingham, The

Society for Research into Higher Education \& Open University, Buckingham.

Noor, K. M. (2013). Job satisfaction of academics in Malaysian public higher

education institutions. A Doctor of Philosophy thesis, La Trobe Business School Faculty of Business, Economics and Law, La Trobe University.

Klassen, R. M., \& Chiu, M. M. (2010). Effects on teachers' self-efficacy and job satisfaction: Teacher gender, years of experience, and job stress. Journal of educational Psychology, 102(3), 741.

Kledaras, C. G. and D. Joslyn. 1992-1993. Job satisfaction as viewed by social work educators.

The Journal of Applied Social Sciences, 17 (1): 1-12. 
INTERNATIONAL JOURNAL OF ACADEMIC RESEARCH IN BUSINESS AND SOCIAL SCIENCES Vol. 8, No. 10, Oct. 2018, E-ISSN: 2222-6990 @ 2018 HRMARS

Kowalczyk, D. (2013). Purposes of Research: Exploratory, Descriptive \& Explanatory. Retrieved from http://education-portal.com/academy/lesson/purposes -of research-exploratorydescriptive-explanatory.html\#lesson

Kosteas, V.D. (2009), Job Satisfaction Promotions, Cleveland State University, Cleveland, OH.

Kreitner, R., \& Kinicki, A. (2001). Organizational behavior (5th ed.). New York: Mc Graw-Hill Inc.

Kusku, F. (2003). Employee satisfaction in higher education: the case of academic and administrative staff in Turkey. Career Dev. Int. 8(7): 347-356.

Locke, E. A. (1969). What is Job Satisfaction? OB and Human Performance, Vol. 4, pp 309-336. Likert, R. (1932). A Technique for the Measurement of Attitudes. Archives of Psychology, 140, 1-55.

Lillydahl, J. H. and L. D. Singell. (1993). Job satisfaction, salaries and unions: the determination of university faculty compensation. Economics of Education Review, 12 (3): 233-243.

Maslow, A. H. (1943). A theory of human motivation. Psychological review, 50(4), 370.

Maslow, A., \& Lewis, K. J. (1987). Maslow's hierarchy of needs. Salenger Incorporated, 14, 987.

Madison, D. (2000). Can your job make you sick? Retrieved from http://www.keepmedia\%20\%20Psychology20

Modeus, G. and Blomkvist (2013). Social Media - Integrate it and Perform Better? Retrieved from www.diva-portal.org

Moos, R. H. (198 1). Work Environment Scale Manual. Palo Alto, CA: Consulting Psychologists Press.

Mukaka, M. M. (2012). A guide to appropriate use of correlation coefficient in medical research. Malawi Medical Journal, 24(3), 69-71.

Mustapha, N., \& Zakaria, Z. C. (2013). The Effect of Promotion Opportunity in Influencing Job Satisfaction among Academics in Higher Public Institutions in Malaysia. International Journal of Academic Research in Business and Social Sciences. 3(3), 20-26.

Mustapha, N. (2013). The Influence of Financial Reward on Job Satisfaction among Academic

Staffs at Public Universities in Kelantan, Malaysia. International Journal of

Business and Social Science. 4(3), 244-248.

Mustapha, N. (2013). Measuring Job Satisfaction from the Perspective of Interpersonal Relationship and Faculty Workload among Academic Staff at Public Universities in Kelantan, Malaysia1. International Journal of Business and Social Science, 4(15).

Nabi, G. R. (1999). An investigation into the differential profile of predictors of objective and subjective career success. Career Development International, 4(4), 212 - 224.

Nabi, G. R. (2003). Situational characteristics and subjective career success. The mediating role of career-enhancing strategies. International Journal of Management, 24(6), 653-671.

Noordin F, Jusoff K (2009) Levels of Job Satisfaction amongst Malaysian Academic Staff. Asian Social Science 5.

Ngah, R., Jusoff, K., \& Rahman, Z. A. (2009). Emotional intelligence of Malaysian Academia towards work performance. International education studies, 2(2), 103.

Noordin, F., \& Jusoff, K. (2009). Levels of job satisfaction amongst Malaysian academic staff. Asian Social Science, 5(5), 122.

Noordin, F., \& Jusoff, K. (2009). Levels of job satisfaction amongst Malaysian academic staff. 
INTERNATIONAL JOURNAL OF ACADEMIC RESEARCH IN BUSINESS AND SOCIAL SCIENCES

Vol. 8, No. 10, Oct. 2018, E-ISSN: 2222-6990 ㄷ 2018 HRMARS

Asian Social Science Journal, 5(5) 122-126.

Mustapha, N. (2013). The influence of financial reward on job satisfaction among

academic staffs at public universities in Kelantan, Malaysia. International Journal

Business and Social Science, Vol. 4 No. 3: $244-248$.

Okpara, J.O., Squillace, M., Erondu, E.A. (2005). Gender differences and job satisfaction: a study of university teachers in the United States. Women Manage. Rev. 20(3): 177-190.

Spector, P.E. (1997). Job Satisfaction: Application, Assessment, Causes, and Consequences.

Thousand Oaks, CA: Sage.

Seidou, M. (1999), "IIUM lecturer participation in academic adminstrative and university policy decision-making", unpublished master thesis, submitted in partial fulfilment of the requirement for the digree of master of Education, Kulliyah of Islamic Revealed

Knowledge \& Human Sciences. International Islamic University, Kulliyah.

Shamoo, A.E., Resnik, B.R. (2003). Responsible Conduct of Research. Oxford University Press.

Suthukar, K. (1997), "Salary increase won't stop brain drain", STAR, 3 July, p. 14.

Srivastava, A. K. (2008). Effect of perceived work environment on employees' job behaviour

and organizational effectiveness. Journal of the Indian Academy of Applied Psychology, 34(1), 47-55.

Spector, P. E. (1982). Behaviour in organisations as a function of employee's locus of control. Psychological Bulletin, 91, 482-497.

Shafiq, M. M., Naseem, M. A. (2011). Association between Reward and Employee Motivation: A case study Banking Sector of Pakistan.

Skaalvik, E. M., \& Skaalvik, S. (2007). Dimensions of teacher self-efficacy and relations with strain factors, perceived collective teacher efficacy, and teacher burnout. Journal of Educational Psychology, 99, 611- 625.

Stephen P. R. (2005), "Organisational Behavior", Ninth Edition, San Diego State University, Pp. 22, 156.

Tan, H. L. (2011). Factors that influence employees' job satisfaction in hotel and catering industry. Doctoral dissertation, University Malaysia Sarawak, UNIMAS.

Tang, T. L. and Talpade, M. (1999). Sex differences in satisfaction with pay and co-workers: faculty and staff at a public institution of higher education. Public Personnel Management, 28 (3): 345-349.

Ting, Y. (1997). Determinants of job satisfaction of federal government employees. Public Personnel Management, 26(3), 313-334.

Tnash, S. (1990). Work satisfaction among the faculty members of the University of Jordan. Dirasat Journal, 17(3).

Oshagbemi, T. (1999) "Overall job satisfaction: how good are single versus multiple-item measures?", Journal of Managerial Psychology, Vol. 14 Issue: 5pp.388-403. 